Creating Productive and Upcoming Sport Education Profesional Hmzanwadi University

Vol.4, No.1, Juni 2021, Hal. 1-7

e-ISSN 2614-8781

\title{
PENGARUH MEDIA PEMBELAJARAN INTERAKTIF TERHADAP HASIL BELAJAR PENDIDIKAN JASMANI SELAMA MASA PANDEMI COVID-19
}

\author{
Yudo Harvianto ${ }^{1}$ \\ email: yudo@fkip.upr.ac.id ${ }^{1}$ \\ ${ }^{1}$ Pendidikan Jasmani, Kesehatan dan Rekreasi, FKIP, Universitas Palangka Raya
}

\begin{abstract}
Abstrak
Bagi seorang pendidik, media pembelajaran dapat dijadikan sebagai alat untuk menyampaikan materi yang telah direncanakan. Sebab salah satu manfaat penggunaan media pembelajaran yaitu mempermudah seorang pendidik untuk menjelaskan materi yang disampaikan agar tujuan pembelajaran dapat tercapai. Terlebih dengan adanya pandemi Coronavirus Disease-2019 (COVID 19) ini, seluruh program sekolah dari bidang kurikulum akan mengalami perubahan pembelajaran. Perubahan tersebut pastinya menuju ke Sistem Pembelajaran Daring ( Dalam Jaringan ). Dari adanya pandemi ini, maka seluruh tenaga pendidik dan peserta didik akan dituntut untuk terjun ke dunia teknologi. Salah satu media yang dapat digunakan dalam proses pembelajaran berbasis online, agar tujuan pembelajaran tercapai yaitu media pembelajaran interaktif berbasis Information and Communication Technology (ICT). Pada prosesnya, ICT dalam suatu pembelajaran dapat dimanfaatkan untuk media presentasi pembelajaran dan media pembelajaran mandiri. Semakin majunya teknologi saat ini, maka menjadi penting bagi seorang tenaga pendidik memiliki pengetahuan yang mendalam tentang teknologi informasi, sehingga dapat dijadikan sebagai media pembelajaran. Adapun yang menjadi tujuan utama dalam penelitian ini yaitu untuk mengetahui pengaruh media pembelajaran interaktif terhadap hasil belajar selama masa pandemi covid-19. Metode penelitian yang digunakan peneliti adalah metode eksperimen dengan desain pre-eksperimental. Peneliti menggunakan pendekatan kuantitatif. Data hasil pretes menunjukkan bahwa hasil belajar peserta didik cenderung rendah. Kemudian setelah dilakukan perlakuan dengan penggunaan media pembelajaran interaktif kepada peserta didik menunjukkan bahwa terjadi peningkatan hasil belajar. Ini membuktikan bahwa perlakuan yang digunakan dengan menggunakan media pembelajaran interaktif guna peningkatan hasil belajar terbilang berhasil.
\end{abstract}

Kata Kunci : Media, Pembelajaran Interaktif, Hasil Belajar, Pendidikan Jasmani, Covid-19

\section{Abstract}

For an educator, learning media can be used as a tool to deliver materials that have been planned. Because one of the benefits of using learning media is to make it easier for an educator to explain the materials delivered so that learning objectives can be achieved. Moreover, with the Coronavirus Disease-2019 (COVID 19) pandemic, all school programs from the curriculum field will experience changes in learning.The change certainly leads to the Online Learning System. The pandemic requires all educators and students to enter the world of technology. One of the media that can be used in the online-based learning process, so that the learning objectives are achieved, namely interactive learning media based on Information and Communication Technology (ICT). In the process, ICT in a learning can be used for learning presentation media and self-learning media. The more advanced technology today, it becomes 
important for an educator to have a deep knowledge of information technology, so that it can be used as a medium of learning. The main objective in this study is to find out the influence of interactive learning media on learning outcomes during the covid-19 pandemic. The research method used by researchers is an experimental method with pre-experimental design.Researchers use a quantitative approach. The data of pretest results showed that the learning outcomes of learners tend to be low.Then after treatment with the use of interactive learning media to students showed that there was an improvement in learning outcomes. This proves that the treatment used by using interactive learning media to improve learning outcomes is successful.

Keywords : Media, Interactive Learning, Learning Outcomes, Physical Education, Covid-19

\section{A. Pendahuluan}

Bagi kehidupan manusia, pendidikan merupakan salah satu faktor yang sangat penting. Sebab pendidikan bisa mempengaruhi keadaan ekonomi dan kualitas hidup seseorang. Selain itu juga bahwa pendidikan dapat dijadikan sebagai salah satu indikator guna mengukur kualitas sumber daya manusia suatu bangsa. Sehingga tercapainya tujuan pembelajaran dalam sebuah pendidikan wajib untuk tertunaikan. Salah satu cara yang dapat dilakukan untuk mencapai keberhasilan tujuan pembelajaran dengan menggunakan media pembelajaran. Bagi seorang pendidik, media pembelajaran dapat dijadikan sebagai alat untuk menyampaikan materi yang telah direncanakan. Sebab salah satu manfaat penggunaan media pembelajaran yaitu mempermudah seorang pendidik untuk menjelaskan materi yang disampaikan agar tujuan pembelajaran dapat tercapai. Terlebih dengan adanya pandemi Coronavirus Disease-2019 (COVID 19) ini, seluruh program sekolah dari bidang kurikulum akan mengalami perubahan pembelajaran. Perubahan tersebut pastinya menuju ke Sistem Pembelajaran Daring (Dalam Jaringan). Dari adanya pandemi ini, maka seluruh tenaga pendidik dan peserta didik akan dituntut untuk terjun ke dunia teknologi. Berdasarkan Surat Edaran Rektor Universitas Palangka Raya, No. 11/UN24/LL/2020 Tentang Pencegahan Perkembangan dan Penyebaran Corona Virus Disease (COVID-19) di Lingkungan Universitas Palangka Raya. Guna pencegahan dan perkembangan COVID-19, Universitas Palangka Raya mengambil langkah-langkah kewaspadaan dan pencegahan penyebaran infeksi COVID-19, diantaranya menetapkan kegiatan belajar mengajar dalam bentuk tatap muka ditiadakan, diganti dengan pembelajaran berbasis online.

Salah satu media yang dapat digunakan dalam proses pembelajaran berbasis online, agar tujuan pembelajaran tercapai yaitu media pembelajaran interaktif berbasis Information and Communication Technology (ICT). Pada prosesnya, ICT dalam suatu pembelajaran dapat dimanfaatkan untuk media presentasi pembelajaran dan media pembelajaran mandiri. Menurut (Chibuife et al., 2018) berpendapat bahwa munculnya ICT di abad ini merupakan perkembangan teknologi yang signifikan sebagai penunjang dalam proses belajar mengajar. Menurut (Collins, 2011) dengan semakin majunya teknologi informasi secara global saat ini, maka menjadi penting bagi seorang tenaga pendidik memiliki pengetahuan yang mendalam tentang teknologi informasi, sehingga dapat dijadikan sebagai media pembelajaran. Sedangkan menurut (Rodríguez Quijada, 2015) ICT menawarkan berbagai macam kemajuan teknologi yang dapat digunakan untuk melengkapi kegiatan dan pengetahuan yang diajarkan tenaga pendidik kepada peserta didik. Berdasarkan latar belakang diatas, peneliti akan melakukan penelitian tentang "pengaruh media pembelajaran interaktif terhadap hasil belajar pendidikan jasmani selama masa pandemi covid-19. Adapun yang menjadi tujuan utama dalam penelitian ini yaitu untuk 
mengetahui pengaruh media pembelajaran interaktif terhadap hasil belajar pendidikan jasmani selama masa pandemi covid-19.

\section{Media Pembelajaran Interaktif}

Menurut (Arsyad, 2011) media adalah semua bentuk perantara yang digunakan oleh manusia untuk menyampaikan atau menyebar ide, gagasan atau pendapat, sehingga ide, gagasan atau pendapat yang dikemukakan itu sampai kepada penerima yang dituju. Dalam konteks dunia pendidikan, (Arsyad, 2011) mengungkapkan bahwa media secara garis besar adalah manusia, materi, atau kejadian yang membangun kondisi yang membuat siswa mampu memperoleh pengetahuan, keterampilan, atau sikap. sehingga media pembelajaran dapat diartikan sebagai alat yang digunakan dalam proses pembelajaran guna tersampaikannya informasi dari tenaga pendidik ke peserta didik agar tujuan pembelajaran tercapai. Menurut (Djamarah, S, B. Zain, 2006) menyatakan bahwa ada beberapa jenis-jenis media pembelajaran yaitu: (a) media auditif, yaitu media yang mengandalkan kemampuan suara saja (radio, kaset rekorder), (b) media visual, yaitu media yang hanya mengandalkan indera penglihatan karena hanya menampilkan gambar diam (film, bingkai, foto, gambar, atau lukisan), (c) media audiovisual yaitu media yang mempunyai unsur suara dan unsur gambar. jenis media ini mempunyai kemampuan yang lebih baik. Menurut (Widjayanti et al., 2018) media pembelajaran berbasis TIK dapat melatih kemandirian siswa, siswa dapat belajar secara mandiri tanpa harus disertai peran seorang guru, karena siswa dapat berinteraksi dengan media seperti halnya berinteraksi dengan guru, media semacam ini disebut media interaktif.

\section{Hasil belajar}

Hasil belajar adalah sebagai terjadinya perubahan tingkah laku pada diri seseorang yang dapat diamati dan diukur bentuk pengetahuan, sikap dan keterampilan (Hamalik, 2011). perubahan tersebut dapat diartikan sebagai terjadinya peningkatan dan pengembangan yang lebih baik dari sebelumnya dan yang tidak tahu menjadi tahu. Menurut (Purwanto, 2019) hasil belajar diukur untuk mengetahui pencapaian tujuan pendidikan, sehingga hasil belajar harus paralel dengan tujuan pendidikan, selain itu juga bahwa hasil belajar merupakan perubahan perilaku yang dicapai setelah anak mengikuti proses belajar mengajar.

\section{Pendidikan Jasmani}

Pendidikan jasmani adalahsatu-satunya mata pelajaran di sekolah di mana anak-anak memiliki kesempatan untuk belajar keterampilan motorik dan mendapatkan pengetahuan untuk berpartisipasi dalam berbagai aktivitas fisik atau olahraga (Le Masurier \& Corbin, 2006). Aktivitas fisik yang dilakukan dapat menjadikan tubuh siswa menjadi bugar, kebugaran dapat mewujudkan peningkatan terhadap kualitas hidup siswa dalam beraktivitas (Harvianto, 2020a). Selain itu juga bahwa kelebihan lainnya dari olahraga bisa dijadikan sebagai instrumen untuk mencapai tujuan tertentu (Harvianto, 2020b).

\section{Covid-19}

Pada akhir tahun 2019 sampai dengan awal tahun 2020, dunia dikejutkan dengan ditemukannya virus baru dari Wuhan, Provinsi Hubei dibagian negara Republik Rakyat China yang menjadi wabah global hingga saat ini. Virus ini diberi nama Coronavirus Disease 2019 (COVID-19) yang disebabkan oleh Severe Acute Respiratory Syndrome Coronavirus-2 (SARS- 
CoV-2). Virus Corona Disease 2019 (COVID-19) merupakan penyakit infeksi yang menyerang saluran pernapasan.

\section{B. Metode}

Metode penelitian yang digunakan peneliti adalah metode eksperimen dengan desain preeksperimental. Peneliti menggunakan pendekatan kuantitatif. Metode eksperimen dalam penelitian ini digunakan untuk mengukur perubahan yang terjadi setelah dilakukannya perlakuan. Sampel dalam penelitian ini yaitu mahasiswa PJKR FKIP UPR berjumlah 34 orang. Penelitian ini dilakukan selama 3 bulan. Dalam penelitian ini, peneliti memberikan tes awal (pretest) pada peserta didik guna mengetahui sejauh mana pengetahuan yang dimiliki peserta didik. Setelah diberikan tes awal, peneliti melakukan eksperimen dengan memberikan perlakuan berupa pembelajaran jarak jauh. Pembelajaran jarak jauh atau online dengan media ICT berbentuk media pembelajaran interaktif berupa aplikasi macromedia flash. Kegiatan akhir yang peneliti lakukan yaitu dengan memberikan tes akhir (posttest), dengan tujuan untuk mendapatkan perbandingan data dari tes awal (pretest) ke tes akhir (posttest).

\section{Hasil dan Pembahasan}

Hasil

1. Deskripsi Data Hasil Tes

Tabel 1. Data Nilai Pretes dan Postes

\begin{tabular}{ccc} 
Statistik & Pretes & Postes \\
\hline Jumlah Siswa & 34 & 34 \\
Nilai tertinggi & 84 & 92 \\
Nilai terendah & 48 & 76 \\
Rata-rata & 74 & 86 \\
\hline
\end{tabular}

Data hasil pretes menunjukkan bahwa hasil belajar peserta didik cenderung rendah. Sedangkan setelah penggunaan media pembelajaran interaktif dapat dilihat dari data hasil postes yang menunjukkan bahwa terjadi peningkatan hasil belajar.

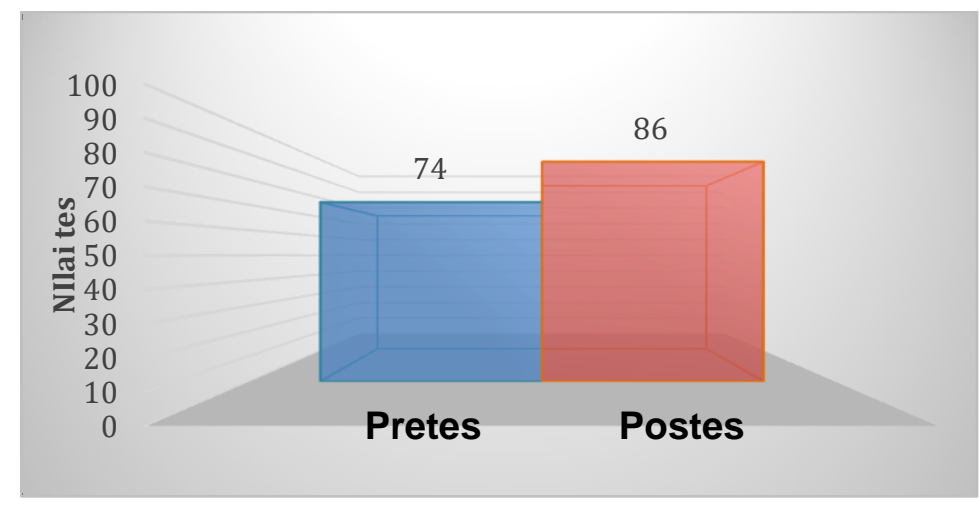

Gambar 1. Perbandingan nilai rata-rata hasil pretes dan postes 
2. Uji Prasyarat Analisis Data

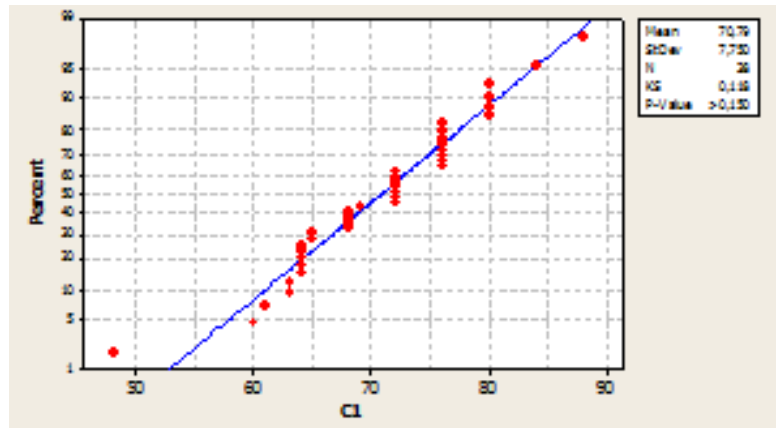

Gambar 2. Hasil uji normalitas data pretes dan postes

Hasil P-Value nilai pretes menunjukan bahwa data beristribusi normal karena telah memenuhi kriteria P-Value $>\alpha$ yaitu $(>0,150>0,05)$.

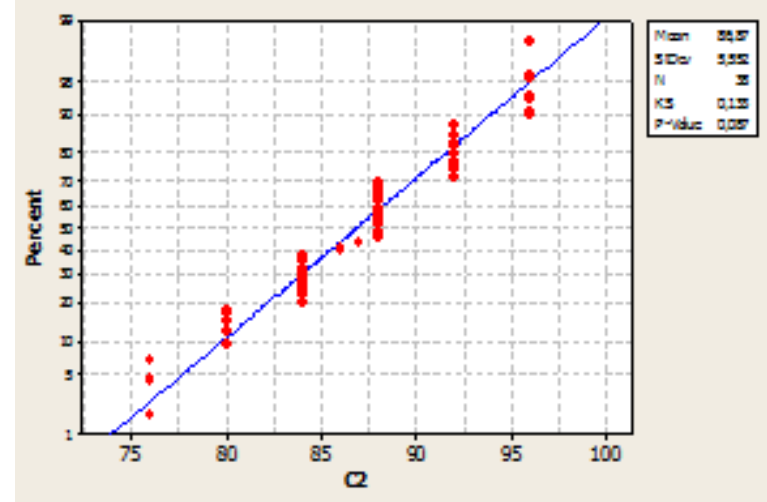

Gambar 3. Hasil uji normalitas data pretes dan postes

Hasil P-Value nilai postes menunjukan bahwa data beristribusi normal karena telah memenuhi kriteria P-Value $>\alpha$ yaitu $(0,087>0,05)$.

\section{Pengujian Hipotesis}

Setelah dilakukan uji prasyarat analisis data, diketahui bahwa data hasil pretes dan postes pada penelitian ini berdistribusi normal, sehingga penggujian data selanjutnya menggunakan uji statistik parametrik yaitu Uji $\mathrm{T}$ untuk dua sampel berpasangan. Uji $\mathrm{T}$ dalam penelitian ini menggunakan aplikasi Minitab. Pengujian hipotesis ini dilakukan untuk mengetahui apakah terdapat perbedaan hasil belajar peserta didik dengan penggunaan media pembelajaran interaktif terhadap hasil belajar. Adapun kriteria hasil Uji T untuk dua sampel berpasangan yaitu jika nilai $\mathrm{P}-$ Value $\leq \alpha$ maka Ho ditolak yang artinya terdapat perbedaan hasil belajar peserta didik dengan penggunaan media pembelajaran interaktif. Sedangkan jika P-Value $>\alpha$ maka Ho diterima yang artinya tidak terdapat perbedaan hasil belajar peserta didik dengan penggunaan media pembelajaran interaktif. 
Creating Productive and Upcoming Sport Education Profesional Hmzanwadi University

Vol.4, No.1, Juni 2021, Hal. 1-7

e-ISSN 2614-8781

Tabel 2. Uji T untuk Dua Sampel Berpasangan

Hasil

\begin{tabular}{ccc}
\hline P-Value & $\alpha$ & Ket. \\
$0,000<$ & 0,05 & Ho ditolak \\
\hline
\end{tabular}

Berdasarkan tabel diatas dapat disimpulkan bahwa terdapat perbedaan hasil belajar peserta didik dengan penggunaan media pembelajaran interaktif.

Pembahasan

Data hasil pretes menunjukkan bahwa hasil belajar peserta didik cenderung rendah. Kemudian setelah dilakukan perlakuan dengan penggunaan media pembelajaran interaktif kepada peserta didik menunjukkan bahwa terjadi peningkatan hasil belajar. Ini membuktikan bahwa perlakuan yang digunakan dengan menggunakan media pembelajaran interaktif guna peningkatan hasil belajar terbilang berhasil. Hal ini sejalan dengan apa yang dikatakan oleh (Stanescu, M. Stoicescu, M. Ciolca, 2011) bahwa penggunaan ICT akan membuat proses pembelajaran menjadi efektif. Sebab dengan terjadinya pembelajaran yang efektif maka akan meningkatkan terhadap informasi yang diberikan melalui metode pembelajaran visual, audio dan kinestetik dalam pembelajaran. Dengan adanya penjelasan diatas menunjukkan bahwa media pembelajaran interaktif bisa dijadikan sebagai media pembelajaran dalam proses pembelajaran oleh tenaga pendidik guna tercapainya tujuan pembelajaran. Sehingga bisa diartikan bahwa tujuan pembelajaran dapat dipengaruhi oleh media yang digunakan dalam proses pembelajaran. Pernyataan diatas sejalan dengan yang dikatakan oleh (Collins, 2011), semakin majunya teknologi informasi, maka menjadi penting bagi seorang tenaga pendidik untuk memiliki pengetahuan yang mendalam tentang teknologi informasi, sehingga dapat dimanfaatkan sebagai media pembelajaran.

\section{Simpulan}

Kesimpulan dari penelitian ini menunjukkan bahwa penggunaan media pembelajaran interaktif selama masa pandemi covid-19 terbukti efektif terhadap peningkatan hasil belajar peserta. Pemanfaatan media pembelajaran interaktif selama masa pandemi covid-19 dapat digunakan untuk membantu tenaga pendidik dalam menyampaikan informasi atau pengetahuan yang akan disampaikan kepada peserta didik yang saat ini belum memungkinkan untuk melakukan perkuliahan secara tatap muka.

\section{Daftar Pustaka}

Arsyad, A. (2011). Media Pembelajaran. PT. Raja Grafindo Persada.

Chibuife, D., Ayalogu, J., \& Aniodo, D. (2018). ICT And The Teaching And Learning Of Physical And Health Education In Secondary Schools In Nigeria. 5 (September), 53-66.

Collins, O. O. (2011). the Use of Ict in Teaching and Learning the Pervasive Solution . Continental J. Education Research, 4 (2), 29-32. http://www.wiloludjournal.com

Djamarah, S, B. Zain, A. (2006). Strategi Belajar Mengajar. PT. Rineka Cipta.

Hamalik, O. (2011). Proses Belajar Mengajar (1st ed.). Bumi Aksara.

Harvianto, Y. (2020). Kebugaran Jasmani (Y. Wisman (ed.); 1st ed.). K-Media. 
Creating Productive and Upcoming Sport Education Profesional Hmzanwadi University

Vol.4, No.1, Juni 2021, Hal. 1-7

e-ISSN 2614-8781

Harvianto, Y. (2020). Strengthening the Brotherhood of Ethnic Groups Rope Through Sport. https://doi.org/10.2991/assehr.k.200219.023

HUdah, M., Widiyatmoko, F. A., Pradipta, G. D., \& Maliki, O. (2020). Analisis Pembelajaran Pendidikan Jasmani Di Masa Pandemi Covid-19 Di Tinjau Dari Penggunaan Media Aplikasi Pembelajaran Dan Usia Guru. Jurnal Porkes, 3 (2), 93-102.

Isnaini, L. M. Y. (2019). Aplikasi Latihan Mental Dalam Pembelajaran Gerak Untuk Meningkatkan Keterampilan Pada Pembelajaran Pendidikan Jasmani Olahraga dan Kesehatan. Jurnal Porkes, 2 (1), 17-25.

Juliati, R. R., Iqbal, R., \& Nurwansyah, R. (2019). Hubungan Kepemimpinan dan Kemampuan Melaksanakan Proses Belajar Dengan Hasil Belajar Pendidikan Jasmani. Jurnal Porkes, 2 (2), 44-49.

Le Masurier, G., \& Corbin, C. B. (2006). Top 10 Reasons for Quality Physical Education. Journal of Physical Education, Recreation \& Dance, 77 (6). https://doi.org/10.1080/07303084.2006.10597894

Purwanto, N. (2019). Tujuan Pendidikan Dan Hasil Belajar: Domain Dan Taksonomi. Jurnal Teknodik, 146. https://doi.org/10.32550/teknodik.v0i0.541

Rodríguez Quijada, M. (2015). Information and communication technologies (ICT) in physical education. A theoretical review. Sportis: Revista Técnico-Científica Del Deporte Escolar, Educación Física $y \quad$ Psicomotricidad, $1(1), \quad 75-86$. http://dialnet.unirioja.es/servlet/articulo?codigo=4942267\&info=resumen\&idioma=ENG

Saputro, A. A., Saputra, Y. D., \& Prasetyo, G. B. (2020). Analisis Dampak Covid-19 Terhadap Kesadaran Masyarakat Dalam Penerapan Protokol Kesehatan. Jurnal Porkes, 3 (2), 8192.

Stanescu, M. Stoicescu, M. Ciolca, C. (2011). Computer use in Physical Education and Sports Teaching. The 7th International Scientific Conference E-Learning and Software for Education Bucharest, April 28-29. 2011. https://doi.org/10.5958/22497315.2015.00086.6

Widjayanti, W. R., Masfingatin, T., \& Setyansah, R. K. (2018). Media Pembelajaran Interaktif Berbasis Animasi Pada Materi Statistika Untuk Siswa Kelas 7 Smp. Jurnal Pendidikan Matematika, 13(1), 101-112. https://doi.org/10.22342/jpm.13.1.6294.101-112 